\title{
ANKARA 9. BÖLGE ECZANELERIINDE ÇALIŞAN ECZACILARIN BAZI MESLEKİ UYGULAMALARINI VE SORUNLARINI SAPTAMA ARAŞTIRMASI
}

\section{A RESEARCH OF DETERMINATION OF SOME OCCUPATIONAL PRACTICES $\&$ PROBLEMS OF PHARMACISTS IN THE $9^{\text {th }}$ REGION OF ANKARA CITY}

\section{K. Hakan ALTINTAŞ ${ }^{1}$, Banu ÇAKIR ${ }^{1}$, Fehminaz TEMEL ${ }^{1}$, Sinan BAHADHt ${ }^{2}$, Ahmet BURAKGAZI ${ }^{2}$, Murat ÇilLOĞLU ${ }^{2}$, Çağdaş DOĞAN² ${ }^{2}$, Mohammed JEHAİSH ${ }^{2}$, Cenk SERIN ${ }^{2}$}

\author{
${ }^{1}$ University of Hacettepe, Faculty of Medicine, Department of Public Health, 06100, Sthhiye - \\ Ankara, TURKEY \\ ${ }^{2}$ University of Hacettepe, Faculty of Medicine, 06100 Sihhiye- Ankara, TURKEY
}

\section{ÖZET}

Nisan 2003'de, Ankara 9. Bölgedeki eczanelerde çalışan eczacıların bazı mesleki uygulamalarının ve sorunlarının saptanmasına yönelik bir araştırma yapılmıştır. Bu araştırma kesitsel tipte bir epidemiyolojik çalışmadır. Araştırmanın verileri yüz yüze anket uygulama yöntemiyle toplanmıştır. Ankara 9. Bölgedeki tüm eczaneler (99 eczane) araştırmanın kapsamına alınmıştır, katılım \%89.9 (89 eczane-eczacl) olarak gerçekleşmiştir.

Araştırmaya katılan eczacıların \%14.8'inin eczacı olmaktan, \%12.5'inin de hizmet verdikleri bölgeden memnun olmadıklarl belirlenmiştir. Eczacılık meslĕginin en önemli sorunu olarak, "sorunlu geri ödemeler" (\%40.7) belirtilmiştir. Eczacıların \%17.1'inin sağllk hizmetine olan katkılarını yetersiz buldukları saptanmıştır.

Eczacıların, eczanede en sık yaptıkları tıbbi girişimin kan basıncı ölçme (\%82.0) olduğu görülmüştür ve \%29.2 'sinin kendilerini ilk yardım konusunda yetersiz buldukları saptanmıştır.

Ocak 2003'de "eşdeğer ilaç uygulaması ve ilaç katılım payının kaynă̆ından kesilmesi" adıyla iki düzenleme getirilmiştir. Eczacılardan \%92.2'sinin Emekli Sandĭ̆ı'nın eşdeğer ilaç uygulamasından memnun olmadıklarl saptanmıştır. Memnun olmama nedenleri içinde ilk sirayı hastayla yaşanan sorunlar almaktadır. Eczacıların \%92.1'inin ilaç katılım paylarının kaynă̆ından kesilmesi uygulamasından memnun olduklarl belirlenmiştir. Memnun olma nedenleri içinde ilk sırayı hasta ile yaşanan para sorunlarının çözülmesi almaktadır.

Anahtar Sözcükler: Eczacı, mesleki sorunlar, mesleki uygulamalar, eşdeğer ilaç. 


\begin{abstract}
In April, 2003, this study was conducted to determine sotne of the occupational practices and problems of pharmacists in the $g^{\text {th }}$ region of Ankara City. This research is a cross-sectional epidemiological study. Data was collected by face to face interview technique. Ali pharmacists (99 pharmacists) in the 9th region of Ankara city were included in this study. A total of 89 pharmacists were surveyed. Participation rate was $89.8 \%$.

It's determined that of ali pharmacists who participated in the study, $14.8 \%$ were not satisfied with their jobs and $12.5 \%$ with their service areas. Of the participants, $13.6 \%$ thought that the medical doctors never understood their contribution to health services. it's understood that the most important problem in profession was the failure of getting drug fees from the institutions (40.7\%). Of the participants, $17.1 \%$ said that their contribution to health services was insufficient. Measurement of the blood pressure was the most oftenly applied medical practise (82.0\%) in the pharmacies. It's determined that 29.2\% of the pharmacists evaluated themselves as insufficient infirst-aid.

in January2003, two new regulations named " generic drug practise and cutting the drug fee share of the user at the source" were established. Of the pharmacists, $92 \%$ weren't satisfied with generic drug practise. The leading reason of unsatisfaction is the problems faced with the patients. Of the pharmacists, $92.1 \%$ were satisfied with the regulation cutting the drugfee share of the user at the source. The leading reason of satisfaction was the solution of the money problem that was between pharmacist and patient.
\end{abstract}

Key words: Pharmacists, occupational problems, occupational practices, generic drug

\title{
GİRİŞ
}

Eczacılık hiç şüphesiz tarihin en eski mesleklerinden birisidir. Öyle ki ilaçlar ile ilgili en eski bilgilere milattan 3000 yıl kadar önce yazıldı̆̆ı saptanmış olan Sümer tabletlerinde rastlanmıştır. Doktorluk mesleğiyle eczacılık mesleğinin henüz ayrışmadığı, sokak sokak gezilip insanları başına toplayarak ilaçların tanıtılıp satıldığı Roma İmparatorluğu döneminden, bugünkü modern eczacılık anlayışına ulaşılıncaya kadar geçen uzun tarih süreci boyunca eczacılık mesleği daima halk tarafından ihtiyaç duyulan ve rağbet edilen mesleklerden olmuştur (1)

Modern anlayışıyla tanımlanacak olursa eczacı; eczacılık fakültesinden veya eczacılık yüksek okulundan mezun olmuş veya usulüne göre yabancı okullarda eğitiminin yeterliliğini tescil ettirmiş, ilaç ve hammaddelerin elde edilişinde, farmasotik madde ve tıbbi müstahzar yapımında, fiziksel, kimyasal, biyolojik ve toksikolojik analizlerinde, ilacın tanınması, kalitesinin sağlanması, kontrolü ve standardizasyonu, dağıtımı ve hastaya verilmesinde; ilacın kullanım, gözetim ve denetiminde, kısacası ilacın üretiminden tüketimine kadar geçen her aşamada idari ve teknik olarak ve tüm yetki ile görev alan sorumlu kişidir (2). 
Tanımı böyle yapılmakla birlikte teknolojinin gelişmesi ile zaman içerisinde eczacıların görevleri de değişikliğe uğramış, ilaç hazırlamaktan ziyade hazırlanan ilaçların hastalara ulaştırılması ve hastalara ilaçların nasıl kullanılacağı, kullanımının izlenmesi ve ilaçlar hakkında hastaya ve hekimlere bilgi verilmesi doğrultusuna yönelmiştir. Hastalıklarla mücadelede hekimlerin elindeki en önemli unsurlardan biri olan ilaçların, üretilmesinden dağıtılmasına kadar geçen uzun sürecin herhangi bir aşamasındaki aksaklık ve yanlışlıklar, amaçlanan hastalıklarla mücadeleyi aksatabileceği gibi yapılacak bu yanlışlıklar ilaçların bizzat kendilerini toplum sağlı̆̆ını tehdit edici tehlikeli maddeler haline getirebilmektedir. Bu yönden ele alındığında, eczacılığın toplum sağlığı açısından ne denli önemli olduğu daha iyi anlaşılabilir.

$\mathrm{Bu}$ nedenle; Ankara Eczacı Odası'nın (AEO) belirlediği Ankara 9. Bölge sınırları içindeki eczanelerde çalışan eczacıların bazı mesleki uygulamalarını ve sorunlarını; eczacılıkla ilgili yapılan son yasal değişikliklere eczacıların bakışını saptamak üzere bu araştırma yapılmıştır. Bu sayede eczacıların birinci basamak sağlık hizmetlerine olan katkısı ve bu katkıyı yaparken karşılaştıkları sorunlar daha iyi değerlendirilmiş ve yeni yasal uygulamaların ilk sonuçlarına ilişkin fikir sahibi olunmuştur.

Ankara 9. Bölgedeki eczanelerde çalışan eczacıların; bazı sosyodemografik özelliklerini, meslek yaşamları ile ilgili bazı özelliklerini, memnuniyetlerini, bu konudaki bazı görüşlerini, Emekli Sandığı'nın eşdeğer ilaç uygulaması ve ilaç katılım paylarının kaynağından kesilmesi hakkındaki görüşlerinin belirlenmesi araştırmanın amaçlarını oluşturmuştur.

\section{MATERYAL VE YÖNTEM}

Araştırma, AEO'nın belirlemiş olduğu 9. bölgedeki (Keçiören, Sanatoryum, Kuşcağız, Atapark, Ufuktepe, Bademlik ve Aktepe) 99 eczanede çalışan eczacıları kapsamaktadır. Bu evrenden ayrıca bir örneklem seçilmemiştir ve bu eczanelerde görev yapan eczacılardan çalışmaya katılmayı kabul edenlerin hepsi (89 eczane- eczacı, \%89.9) çalışmaya dahil edilmiştir. Yedi eczacı anket yapılmasını reddetmiş, üç eczacıya ise ulaşılamamıştır. Bu araştırma kesitsel tipte epidemiyolojik bir çalışmadır. Eczacının bazı sosyodemografik özellikleri, meslek hayatı ile ilgili bazı özellikleri ve görüşleri araştırmanın değişkenlerini oluşturmuştur.

Araştırıcılar tarafından eczanelere gidilerek, yüz yüze görüşme tekniği ile standart anketler kullanılarak bilgi toplanmıştır. Araştırmada 49 sorudan oluşan bir anket formu kullanılmıştır. Veriler Mart 2003'ün 4. haftasında toplanmış ve SPSS 11.0 bilgisayar programı kullanılarak analiz edilmiştir. İstatistiki değerlendirmede ki-kare testi kullanılmıştır. Ankara Eczacılar Odası'ndan araştırma için yazılı izin, araştırmaya katılan eczacıların ise sözel rızaları alınmıştır. 
14 K. Hakan ALTINTAŞ, Banu ÇAKIR, Fehminaz TEMEL, Sinan BAHADIR, Ahmet BURAKGAZİ, Murat

ÇİLOĞLU, Çağdış DOĞAN, Momammed JEHAİSH, Cenk SERİN

\section{BULGULAR}

Araştırmaya katılan eczacıların \% 19.1'i (17 eczacı) 50 ve üstü yaş grubunda olduklarını belirtmişlerdir. Eczacıların \%53.9'u 40 yaş ve üstünde olduklarını belirtmişlerdir. Eczacıların yaş ortalaması $39.8(\mathrm{SS}=8.7$, alt-üst sınır $=25-56$, ortanca $=40)$ olarak bulunmuştur. Görüşülen eczacıların \%48.3'ü (43 eczacı) kadın, \%51.7'si (46 eczacı) erkektir. Eczacıların \%75.3'ü (67 eczacı) evli olduklarını belirtmişlerdir. Tüm eczacılar içinde \%91.0'ının (81 eczacı) sosyal güvence tipinin Bağ-Kur olduğu tespit edilmiştir.

Araştırmaya katılan eczacıların mezun olduğu fakülteler içinde ilk sırayı \%40.4 (36 eczac1) ile Ankara Üniversitesi Eczacılık Fakültesi'nin aldığı görülmüştür. Ankara'daki eczacılık fakültelerinden mezun olduğunu söyleyen 83 eczacı (\%93.3) vardır. Eczacıların \%39.3'ü (35 eczacı) 1980-1989 yılları arasında mezun olmuştur. Eczacıların \%23.6'sının 1979 ve öncesinde mezun olduğu ve \%40.4'ünün 10-19 yıldır bu meslekte çalıştıkları saptanmıştır. Bu bölgedeki eczacıların meslekte çalıştıkları ortalama süre 15.2 yıl ( $\mathrm{SS}=8.6$, Alt-üst sınır=1-33, Ortanca=15) olarak bulunmuştur. Eczacıların \%7.9'u (7 eczacı) eczacılıkla ilgili yüksek lisans yaptıklarını söylemişlerdir.

Serbest eczacılık yapmadan önce, bir dönem, eczacıların 20'si (\%22.5) kamu, beşi (\%5.6) ilaç firması, üçü (\%3.4) ilaç üretim sektörü, biri (\%1.1) ecza deposu, biri (\%1.1) medikal firmasında çalıştıklarını söylemişlerdir.

Serbest eczacı olarak çalışılan ortalama süre 13.7 yıl $(\mathrm{SS}=8.6$, alt-üst sınır=1-33, ortanca $=14$ ) bulunmuştur. Kamu sektöründe çalışılan ortalama süre 6.1 yıl ( $S S=6.4$, alt-üst sınır $=1-21$, ortanca $=3)$ çıkmıştır. İlaç firmasında çalışılan ortalama süre 4.4 yıl $(\mathrm{SS}=3.5$, alt-üst smır=1-10, ortanca $=4$ ) olarak hesaplanmıştır.

Araştırmaya katılan eczacıların \%98.9'unun (88 eczacı) eczane sahibi ve mesul müdür, \% 1.1'inin (1 eczacı) mesul müdür olarak çalıştı̆̆ 1 anlaşılmıştır. Eczacıların 9. Bölgedeki çalışma yılları ortalaması 11.8 yıl $(\mathrm{SS}=8.2$, alt-üst sınır=1-33, ortanca=12) olarak ve günlük çalışma saatleri ortalaması ise 10.7 saat olarak bulunmuştur. Eczacıların \%70.5'i (63 eczacı) eczanede kendilerinden başka en az bir kişinin daha çalıştığını ifade etmişlerdir. Eczacının yanında çalışan kişiler arasında birinci sırayı kalfa (\%71,44 eczacı) almıştır. 


\section{TABLO1: ECZACILARIN BAZI MESLEKİ GÖRÜŞLERININN VE BAZI GÖSTER- GELERIN YETERLİLIK DÜZEYINII TANIMLAMALARININ ÖZET TABLOSU (ANKARA 9. BÖLGE, NISAN 2003)}

\begin{tabular}{|c|c|c|c|c|c|c|}
\hline \multirow{4}{*}{$\begin{array}{l}\text { Görüş ve } \\
\text { Göstergeler } \\
(\mathrm{n}=88)^{1}\end{array}$} & \multicolumn{6}{|c|}{ Memnuniyet /Yeterlilik Düzeyi } \\
\hline & \multirow{2}{*}{\multicolumn{2}{|c|}{ Memnun değil/Yetersiz }} & \multirow{2}{*}{\multicolumn{2}{|c|}{$\frac{\text { Fena değil/Bir ölçüde }}{\text { yeterli }}$}} & \multirow{2}{*}{\multicolumn{2}{|c|}{ Memnun/Yeterli }} \\
\hline & & & & & & \\
\hline & Say1 & $\%$ & Sayı & $\%$ & Sayı & $\%$ \\
\hline Mesleki memnuniyet & 13 & 14.8 & 37 & 42.0 & 38 & 43.2 \\
\hline $\begin{array}{l}\text { Hizmet verilen bölgeden } \\
\text { memnuniyet }\end{array}$ & 11 & 12.5 & 45 & 51.1 & 32 & 36.4 \\
\hline Sağlık hizmetine katkıları & 15 & 17.1 & 39 & 44.3 & 34 & 38.6 \\
\hline Ortalama aylık kazanç & 15 & 17.0 & 51 & 58.0 & 22 & 25.0 \\
\hline $\begin{array}{l}\text { Yetki ve sorumluluklarını } \\
\text { düzenleyen yasal çerçeve }\end{array}$ & 40 & 45.5 & 36 & 40.9 & 12 & 13.6 \\
\hline $\begin{array}{l}\text { Üniversitede aldığı eğitimi } \\
\text { uygulama imkanı }\end{array}$ & 44 & 50.0 & 39 & 44.3 & 5 & 5.7 \\
\hline $\begin{array}{l}\text { Bilgi ve becerilerini geliştirme } \\
\text { imkanı }\end{array}$ & 34 & 38.7 & 45 & 51.1 & 9 & 10.2 \\
\hline Gelecek güvenceleri & 27 & 30.7 & 47 & 53.4 & 14 & 15.9 \\
\hline Eş değer ilaç uygulaması ${ }^{2}$ & 82 & 94.3 & - & - & 5 & 5.7 \\
\hline $\begin{array}{l}\text { İlaç katılım payının } \\
\text { kaynaktan kesilmesi }{ }^{1.3}\end{array}$ & 5 & 5.7 & - & - & 82 & 94.3 \\
\hline
\end{tabular}

Not: Çalışmaya 89 eczacı katılmıştır

Araştırmaya katılan eczacıların \% 14.8'i (13 eczacı) eczacı olmaktan memnun olmadıklarını belirtmişlerdir (Tablo1). Memnuniyetsizliğe gerekçe olarak; 4 eczacı yoğun çalışma temposunu, 4 eczacı mesleklerini sevmemelerini, 3 eczacı mesleki uygulama sorunlarını, 1 eczacı maddi sorunları ve 1 eczacı da kötü sağlık sistemini belirtmiştir.

Araştırmaya katılan eczacıların \% 12.5'i (11 eczacı) hizmet verdikleri bölgeden memnun olmadıklarını belirtmişlerdir (Tablo1). Memnuniyetsizliğe gerekçe olarak; 3 eczacı eczane sayısının fazla olmasını, 2 eczacı halkın alım gücünün az olmasını, 1 eczacı sosyal adaletsizliği ve 1 eczacı da deontolojiye uyulmamasını belirtmiştir. 4 eczacı gerekçe göstermemiştir.

Eczacıların \% 17.1'i (15 eczacı) sağlık hizmetlerine olan katkılarını yetersiz bulduklarını belirtmişlerdir (Tablo1). Yetersiz bulmalarına gerekçe olarak; 8 eczacı sadece ilaç vermekle görevlerinin yerine getirilmiş olamayacağını, 5 eczacı ilk planda paranın düşünülüyor olmasını, 2 eczacı ise hastaya ilaç hakkında yeterli bilgilendirme yapılmamasını gerekçe olarak 
16 K. Hakan ALTINTAŞ, Banu ÇAKIR, Fehminaz TEMEL, Sinan BAHADIR, Ahmet BURAKGAZİ, Murat ÇİLOĞLU, Çağdış DOĞAN, Momammed JEHAİSH, Cenk SERİN

göstermiştir. Eczacıların \%44.3'ü (39 eczacı) kendilerinin sağlık hizmetlerine olan katkılarını "fena değil", \%38.6'sı (34 eczacı) "yeterli" olarak değerlendirmiştir (Tablo 1).

Araştırmaya katılan eczacıların \% 17'sinin (15 eczacı) ortalama aylık kazançlarının yetersiz olduğunu, \%45.5'inin (40 eczacı) yetki ve sorumluluklarını düzenleyen yasal çerçevenin yetersiz olduğunu, \%50.0'ınm (44 eczac1) üniversitede aldığı eğitimi uygulama imkanlarının yetersiz olduğunu, \%38.7'sinin (34 eczacı) bilgi ve becerisini geliştirme imkanlarının yetersiz olduğunu, \%30.7'sinin (27 eczacı) ise gelecek güvencelerinin yetersiz olduğunu düşündükleri öğrenilmiştir. Eczacıların \%25.0'1 ortalama aylık kazançlarını yeterli bulmaktadır (Tablo 1).

\section{TABLO 2: ECZACILARA GÖRE SAĞLIK HİZMETLERINE KATKILARININ BAZI GRUPLAR TARAFINDAN NE ÖLÇÜDE KAVRANDIĞI (ANKARA 9. BÖLGE, NISAN 2003 )}

\begin{tabular}{|c|c|c|c|c|c|c|}
\hline \multirow[b]{3}{*}{ Grup $(n=88)$} & \multicolumn{6}{|c|}{ Sağıı Hizmetlerine Katkının Kavranması } \\
\hline & \multicolumn{2}{|c|}{ Hiç kavranmıyor } & \multicolumn{2}{|c|}{ Bir Ölçüde kavranıyor } & \multicolumn{2}{|c|}{ Tamamen kavranıyor } \\
\hline & Say1 & Yüzde* & Sayı & Yüzde* & Sayı & Yüzde* \\
\hline Hekimler & 12 & 13,6 & 60 & 68,2 & 16 & 18,2 \\
\hline Hastalar & 1 & 1,2 & 56 & 63,6 & 31 & 35,2 \\
\hline Yakın çevre & 3 & 3,4 & 44 & 50,0 & 41 & 46,6 \\
\hline $\begin{array}{l}\text { Yazılı ve } \\
\text { görsel basın }\end{array}$ & 29 & 32,9 & 52 & 59,1 & 7 & 8,0 \\
\hline
\end{tabular}

*: Satır yüzdesi verilmiştir.

Çalışmada; eczacılara, sağlık hizmetlerine eczacıların katkısının değişik gruplar tarafından ne ölçüde kavrandığı sorulmuştur. Buna göre eczacıların sağlık hizmetine yaptıkları katkıyı tamamen kavrayan gruplar arasında ilk sırayı yakın çevreleri (\%46.6, 41 eczacı), hiç kavramayan gruplar arasındaysa yazılı ve görsel basın (\%32.9, 29 eczacı) almıştır. Eczacıların \%13.6'sı (12 eczacı) hekimlerin, eczacıların sağlık hizmetlerine katkılarını hiç kavramadıklarını söylemişlerdir (Tablo2).

Eczacıların meslekleri ile ilgili belirttikleri tüm sorunlar içinde birinci sırayı \%50.6 (114 sorun) ile ekonomik sorunlar, ikinci sırayı \% 18.2 (41 sorun) ile mesleki saygınlık, meslek ahlakı ve deontolojik sorunlar, üçüncü sırayı \% 15.5 (35 sorun) ile bürokrasi ve kamu sektörü ile ilgili sorunlar almıştır.

Eczacıların \%61.0'i (54 eczacı) mesleğin en önemli birinci sorununu ekonomik sorunlar olarak belirtmişlerdir. Ekonomik sorunlar içerisindeki en büyük payı \%40.7 (35 eczacı) ile sorunlu geri ödemeler almıştır. İkinci en önemli sorun da bürokrasi (\%15.5, 35 eczacı) çıkmıştır. 
Eczacılara göre çalıştıkları bölgedeki en önemli sağlık sorunları içinde birinci sırayı \%57.7 (102 sorun) ile hastalıklar, ikinci sırayı \% 18.1 (132 sorun) ile temel sağlık hizmetleri ile ilgili sorunlar, üçüncü sırayı \%16.9 (30 sorun) ile ekonomik sorunlar almıştır.

Eczacıların \%47.2'si (42 eczacı) bölgenin en önemli sağlık sorununu hastalıklar olarak belirtmişlerdir. Hastalıklar içerisindeki en büyük payı \%36.8 (28 eczacı) ile ÜSYE almıştır.

Eczacıların \% 19.1'inin (17 eczacı) meslek içi eğitim programı (MİEP) düzenleyen kurumlar hakkında hiçbir bilgileri olmadı̆̆ı görülmüştür. Katılımcıların \%80.9'u (72 eczacı) MIEP düzenleyen bir kurumun olduğunu belirtmişlerdir. Kurum belirten eczacıların en çok belirttiği MİEP düzenleyen kuruluş (\%86.1, 62 eczacı) AEO olmuştur. İhtiyaç duyulan konular arasında \%54.4 (75 konu) ile eczacılık uygulamaları ve \%21.7 (30 konu) ile hastalıklar ile ilgili eğitim programları ilk iki sırayı almıştır.

Araştırmaya katılan eczanelere günlük ortalama başvuran kişi sayısının 37.5 kişi $(\mathrm{SS}=20.8$, alt-üst sınır=10-100, ortanca=30.0) olduğu öğrenilmiştir. Eczacıların \%91.2'si (82 eczacı) en sık sağlık ocaklarında düzenlenen reçetelere sahip hastaların kendilerine başvurduğunu belirtmiştir. Eczacıların \%70.8'i (63 eczacı) en sık Emekli Sandığı'nm sağlık güvencesi altında olan hastaların eczanelerine başvurduğunu belirtmişlerdir. Eczacıların \%48.3'ü (43 eczac1) sık sık, doktora gitmeden eczaneye başvuran hasta olduğunu ifade etmişlerdir. Arasına doğrudan eczaneye başvurular da katıldığında bu rakam \%97.8 (87 eczacı) olmuştur.

Araştırmaya katılan eczacıların \%82'si (73 eczacı) kendilerine en yakın sağlık kuruluşunun sağlık ocağı olduğunu belirtmişlerdir. Katılımcıların \%97.8'inin (87 eczacı) Emekli Sandığı ile anlaşması olduğu öğrenilmiştir.

Eczacıların \%96.6'sı (86 eczacı) reçetelerde yazım kuralları ile ilgili eksiklikler olduğunu söylemiştir. En sık görüldüğü söylenen eksiklik okunaksız yazılar (\%53.9, 48 eczacı), ikinci olarak da doz yanlışlıkları (\%51.7, 46 eczacı) olmuştur. Eczacıların \%46.7'si (41 eczacı) eczanelerinde en çok satılan reçeteli ilacı antibiyotik olarak belirtmişlerdir. Eczacıların \%81.9'u (72 eczac1) eczanelerinde en çok satılan reçetesiz ilaç grubunu analjezikler olarak belirtmişlerdir. Eczanelerde en sık talep edilen reçeteli veya reçetesiz ilaçlar arasında analjezikler (\%29.8, 147 adet) ilk sırayı almıştır. Bunu antibiyotikler (\%23.9, 118 adet) ve vitaminler (\%8.1, 40 adet) takip etmiştir.

Çalışmaya katılan 89 eczacıdan 83'ü (\%94.4) eczanesinde majistral ilaç hazırladığını belirtirken 5 eczacı (\%5.6) hazırlamadı̆̆ını söylemiştir.

Eczacıların \%96.6'sı (86 eczacı) ilaç dışı ürün de sunduklarını söylemişlerdir. En sık sunulan ilaç dış1 ürün bebek ürünleri (\%34.9, 30 eczacı) olmuştur.

Eczacıların tamamı (89 eczacı) eczanelerinde gebeliği önleyici hap, \%98.9'u (88 eczacı) ise prezervatif bulunduğunu söylemişlerdir. Eczacılar en çok talep edilen aile planlaması (AP) yönteminin gebeliği önleyici haplar (\%91.0, 81 eczacı) ve prezervatif (\%80.9, 72 eczacı) olarak belirtmişlerdir. Eczacıların \%46.1'i (41 eczacı) AP yöntemlerini, kadın ve erkeklerin her ikisinin de aldığını söylemişlerdir. 
18 K. Hakan ALTINTAŞ, Banu ÇAKIR, Fehminaz TEMEL, Sinan BAHADIR, Ahmet BURAKGAZİ, Murat ÇİLOĞLU, Çağdış DOĞAN, Momammed JEHAİSH, Cenk SERIN

Eczacıların, eczanede en sık yaptıkları tıbbi girişim kan basıncı ölçme (\%82.0, 73 eczacı) olarak saptanmıştır. Eczacıların \%29.2'si (26 eczacı) kan basıncı ölçme konusunda eğitim almıştır. Kan basıncı ölçme konusunda eğitim alan 26 eczacıdan 25'i üniversitede, biri ise Numune Hastanesi'nde bu eğitimi almıştır. Enjeksiyon yaptı̆̆ını söyleyen 6 eczacı arasından enjeksiyon yapma konusunda eğitim alan dört eczacı Kızılay'dan eğitim almıştır .Yüksek tansiyonu düşürmek için acil olarak ilaç veren ve bu konuda eğitim alan dört kişiden üçü üniversitede, bir eczacı ise Numune Hastanesi'nde bu eğitimi almıştır. İlkyardım eğitimi alan 12 eczacıdan $T$ si üniversitede, ikisi Numune Hastanesi'nde, birer kişi ise TEB, TÜBİTAK ve Kızılay'dan eğitimini almıştır. Kulak deldiğini söyleyen 9 eczacıdan hiçbiri bu konuda eğitim almamıştır.

Araştırmaya katılan eczacıların \%91'inin (81 eczacı) ilkyardım sertifikası olmadı̆̆ öğrenilmiştir. Eczacıların \%29.2'sinin (26 eczacı) kendilerini ilkyardım konusunda yetersiz olarak değerlendirdikleri anlaşılmıştır. Eczacıların \%75.3'ünün (67 eczacı) eczanelerinde şu ana kadar ilkyardım müdahalesi yapması gereken bir durum olmamıştır. Eczanelerde ilkyardım müdahalesi yapan eczacılardan 9'u cilt kesişine müdahale yapmıştır. Eczacılardan 7'si travma, 3'ü trafik kazası, 2'si kanamalı hasta ile karşılaşmış ve 1 tanesi kardiyopulmoner resusitasyon yapmıştır.

Araştırmaya katılan eczacıların \%69.7'sinin (62 eczacı) yetki ve sorumluluklarını düzenleyen yasal çerçeveyi mevzuattan, \%58.4'ünün (52 eczacı) fakültede aldıkları eğitimden öğrendiği tespit edilmiştir.

Eczacıların tamamı eczanelerinin denetlendiğini belirtmiştir. Katılımcılar, İl Sağlık Müdürlüğü'nün (\%82.0, 73 eczac1) en sık denetim yapan kurum olduğunu belirtmişlerdir. Eczacıların \%39.3'ü (35 eczacı) üç ayda bir denetlendiklerini söylemişlerdir.

Çalışmaya katılan eczacılardan \%24.0'ü (24 eczacı) son üç ayda eczanelerinde ilaç alımında herhangi bir değişiklik olmadığını, \% 68.5'i ise (61 eczacı) eczanelerinden ilaç alımında azalma olduğunu, \% 3.4'ü de (3 eczacı) artma olduğunu belirtmiştir. Eczacılar ilaç alımındaki azalmaya en önemli gerekçe olarak \%25.8 ile (23 eczacı) ekonomik krizi göstermişlerdir. İlaç katılım payının kaynağından kesilmesi (\%19.1, 17 eczacı), eşdeğer ilaç uygulaması (\%4.5,4 eczacı) da, ilaç alımını azaltan nedenler arasında sayılmıştır.

Araştırmaya katılan eczacılardan \%92.2'si (82 eczacı) Emekli Sandığı'nın eşdeğer ilaç uygulamasından memnun olmadıklarını ifade etmişlerdir (Tablo 1). Memnun olmama nedenleri içinde ilk sırayı \%59.0 (43 eczacı) ile hastayla yaşanan sorunlar almaktadır. Hastayla yaşanan sorunların ise \%17.8'inin (13 eczacı) hastayla karşı karşıya kalmak olduğunu belirtmişlerdir. Memnun olduğunu belirten beş eczacıdan ikisi uygulamanın devlet için karlı ve yararlı bir uygulama olduğunu, biri yolsuzlukların önleneceğini, biri yerli firmaların da kazanacağını ve biri de gereksiz yere pahalı ilaç yazılmadığını belirtmişlerdir.

Eczacıların \%92.1'i (81 eczacı) ilaç katılım paylarının kaynağından kesilmesi uygulamasından memnun olduklarını belirtmişlerdir (Tablo 1). Memnun olma nedenleri içinde ilk sırayı \%54.2 (39 eczacı) ile hasta ile yaşanan para sorunlarının çözülmesi almaktadır. 
Memnun olmayanların üçü ilaç ödemelerinin gecikmesini, bir kişi ticari ilişkilerin azaldığını belirtmiş ve bir kişi de cevap vermemiştir.

Çalışmaya katılan eczacıların \%45.5'i (40 eczacı) ilaç alımının Emekli Sandığı'nın eşdeğer ilaç uygulamasından dolayı azaldığını söylemişlerdir. Eczacıların \%68.2'si (60 eczacı) ilaç alımının ilaç katılım payının kaynağından kesilmesinden dolayı azaldığını belirtmiştir.

Araştırmaya katılan eczacıların \%78.4'ü (69 eczacı) Emekli Sandığı'nın eş değer ilaç uygulamasından hastaların olumsuz etkilendiğini belirtmişlerdir. Eczacıların \%64.4'ü (56 eczacı) ilaç katılım payının kaynağından kesilmesinden dolayı hastaların olumsuz etkilendiğini ifade etmiştir.

Emekli Sandığı'nın eşdeğer ilaç uygulamasının hastaların kendileri için gerekli ilaçları elde etmeleri üzerine olan olumsuz etkileri hakkında görüş bildiren eczacıların \%46.2'si (31 eczacı) hastaların eşdeğer ilaca güven duymadıklarını belirtmişlerdir. Ayrıca 12 eczacı (\% 18.5) hastaların ilaçlarını her ne sebeple olursa olsun değiştirmeyi sevmediklerini ve istemediklerini ifade etmiştir.

İlaç katılım payının kaynağından kesilmesi uygulamasının hastaların kendileri için gerekli ilaçlan elde etmelerine olan olumsuz etkisinin nedenleri arasında \%59.5'i (25 eczacı) hastaların eskiden aldıkları ilaç için para ödemesi yapmadıklarını, ancak son uygulamadan sonra para ödediklerinden dolayı olumsuz etkilendiklerini belirtmişlerdir. Olumlu neden belirtenlerin 6'sı gereksiz ilaç alımının azaldığını, l'i pazarlık olmadığını, l'i elinde para olmasa da hastanın ilaç alabildiğini, 1 kişi de ticari olarak olumsuz olsa da etik olarak olumlu olduğunu belirtmiştir.

Eczacıların yaşları, cinsiyetleri, aylık kazançlarının yeterlilik düzeyi, meslekte geçen yılları ile eczacı olmaktan memnuniyetleri arasında istatistiksel olarak anlamlı bir ilişki bulunmamıştır ( $\mathrm{p}$ değerleri sırasıyla; 0.719,0.232,0.615,0.968).

Eczacıların aylık kazançlarının yeterlilik düzeyini değerlendirmeleri ile hizmet verdikleri bölgeyle ilgili görüşleri arasında istatistiksel olarak anlamlı bir ilişki bulunmamıştır (kikare $=9.36, \mathrm{p}=0.053$ ).

Eczacıların hizmet verdikleri bölgeden memnuniyetleri ile eczacı olmakla ilgili görüşleri arasında istatistiksel olarak anlamlı bir ilişki bulunmuştur (ki-kare=18.13, p=0.001). Hizmet verdikleri bölgeden memnuniyetlerini "memnun değil" olarak nitelendiren eczacıların $\% 27.3$ 'ü (3 eczacı), "orta" diyenlerin \%26.7'si (12 eczacı) ve memnun olduklarını ifade eden eczacıların \%71.9'u (23 eczacı) eczacı olmak ile ilgili görüşlerini "memnun" olarak söylemişlerdir. Buna göre, hizmet verdikleri bölgeden memnuniyetleri artıkça meslekten memnuniyetleri artmaktadır (Tablo 3). 
TABLO 3 : ECZACILARIN HİZMET VERDİKLERİ BÖLGEDEN MEMNUNIYETLERINNE GÖRE ECZACI OLMAKLA İLGİLİ GÖRÜŞLERININ DAĞILIMI (ANKARA 9. BÖLGE, NISSAN 2003)

\begin{tabular}{|c|c|c|c|c|c|c|c|c|}
\hline \multirow{3}{*}{$\begin{array}{l}\text { Hizmet verdikleri } \\
\text { bölge ile ilgili } \\
\text { görüş }\end{array}$} & \multirow{2}{*}{\multicolumn{2}{|c|}{ Memnun değil }} & \multicolumn{3}{|c|}{ Eczacı Olmakla İlgili Görüş } & & & \\
\hline & & & & & & & \multicolumn{2}{|c|}{ Toplam } \\
\hline & Sayı & Yüzde & Say1 & Yüzde & Say1 & Yüzde & Say1 & Yüzde \\
\hline Memnun değil & 3 & 27.3 & 5 & 45.4 & 3 & 27.3 & 11 & 12.5 \\
\hline Orta & 9 & 20.0 & 24 & 53.3 & 12 & 26.7 & 45 & 51.1 \\
\hline Memnun & 1 & 3.1 & 8 & 25.0 & 23 & 71.9 & 32 & 36.4 \\
\hline Toplam & 13 & 14.8 & 37 & 42.0 & 38 & 43.2 & & 100.0 \\
\hline
\end{tabular}

\section{TARTIŞMA}

AEO'nın belirlediği Ankara 9. Bölgedeki eczanelerde çalışan eczacıların bazı mesleki uygulamalarını ve sorunlarını saptamak üzere yapılan çalışmaya 89 eczacı katılmıştır. Bu eczacıların \%53.9'u 40 yaş ve üstünde olduklarını belirtmişlerdir. Görüşülen eczacıların \%51.7'si erkek, \%48.3'ü kadındır. Beken S. ve arkadaşları tarafından Ekim 2001'de yapılan Ankara 6. Bölge Eczanelerinde Çalışan Eczacıların Bazı Mesleki Uygulamaları ve Sorunlarını Saptama araştırmasına göre o bölgedeki eczacıların \%68.8'i 40 yaş ve üzerinde olduklarını belirtmişlerdir. O çalışmadaki eczacıların \%44.2'si erkek, \%55.8'i kadındır (3). Türk Eczacılar Birliği'nin (TEB), Aralık 1999'da yayınladığı Eczacı Profili'ne göre de eczacıların \%49.6'sı 40 yaş ve üstünde; \%46.7'si erkek, \%53.3'ü kadındır (4). Bu durumda, görüşülen eczacıların cinsiyet dağılımına bakıldığında önceden yapılan her iki araştırmaya göre erkek yüzdesinin fazla olduğu; yaş dağılımına bakıldığında ise 9. Bölgede 40 yaş ve üstünde olan eczacıların yüzdesinin Türkiye genelinden yüksek, 6. Bölgede eczacılarınkinden ise düşük olduğu görülmüştür.

Tüm eczacılar içinde \%91.0'ının sosyal güvence tipinin Bağ-Kur olduğu tespit edilmiştir. Beken ve ark. araştırması'na göre o bölgedeki eczacıların \%81.8'inin sosyal güvence tipinin Bağ-Kur olduğu tespit edilmiştir (3). TEB' nin çalışmasına göre eczacıların \%96.1'i Bağ-Kur'a bağlıdır (4). Serbest çalışan eczacıların Bağ-Kur'a bağlı olmaları beklenen bir bulgudur.

Eczacıların mesleki öğrenim durumları ve meslekte geçen yılları incelendiğinde, \%93.3'ünün Ankara ili sınırlarındaki eczacılık fakültelerinden mezun oldukları görülmüştür. Eczacıların \%23.6'sının 1979 ve öncesinde mezun olduğu ve \%40.4'ünün 10-19 yıldır bu meslekte çalıştıkları saptanmıştır. Beken ve ark. araştırmasına göre o bölgedeki eczacıların 
\%83.2'sinin Ankara ili sınırlarındaki eczacılık fakültelerinden mezun oldukları görülmüştür (3). TEB'nin çalışmasına göre ise eczacıların \%36.0'ınm Ankara ili sınırları içindeki eczacılık fakültelerinden ve \%42.0'1nm da 1979 ve öncesinde mezun olduğu saptanmıştır (4).

Ankara 9. Bölge eczacılarının \%7.9'unun yüksek lisans yaptıkları belirlenmiştir. Beken ve ark. araştırmasına göre o bölgedeki eczacıların \%14.3'ü yüksek lisans veya doktora yapmıştır (3). TEB'nin çalışmasına göre eczacıların \%3.8'i yüksek lisans veya doktora yapmıştır (4). Eczacıların \%91.0'ının yüksek lisans veya doktora yapmamış olmaları maddi kaygılardan dolayı serbest eczacıllğa erkenden atılmış olmalarına bağlanabilir.

Eczacıların \%25.0'ı ortalama aylık kazançlarını yeterli bulmaktadır. Şencan N.'nin uzmanlık tezine göre; eczacıların \%85'i ortalama aylık gelirini yeterli bulmaktadır (5). Beken ve ark. araştırmasına göre o bölgedeki eczacıların \% 75.3'ü aylık kazançlarını yeterli bulmuştur (3). Ortalama aylık kazançlarını yeterli görme yüzdeleri arasındaki bu bariz fark, 6. Bölgedeki üniversite hastaneleri ve devlet hastanelerinin fazlalığına, bölgelerin ticari potansiyelleri arasındaki farklılığa, halkın ekonomik düzeyinin Ekim 2001'e göre daha kötüye gitmesine ve son yapılan yasal düzenlemelere bağlanabilir. Ankara 9. Bölge eczanelerinde çalışan eczacıların aylık kazançlarının yeterlilik düzeyi ile mesleki memnuniyetleri arasında istatistiksel olarak anlamlı bir ilişki saptanmamıştır.

Eczacıların şu an çalıştıkları eczanelerdeki meslek yaşamları ile ilgili bazı özellikler incelendiğinde; görüşme yapılan eczacıların \%98.9'unun eczane sahibi ve mesul müdür olduğu, \%1.1'inin mesul müdür olduğu saptanmıştır. Mevzuatta belirtildiği üzere, tüm eczanelerde mesul müdür bulunmaktadır. Eczacıların \%70.5'i eczanelerinde kendilerinden başka en az bir kişinin çalıştı̆̆ını ifade etmiştir. Beken ve ark. araştırması'na göre eczacıların çalıştıkları eczanelerin \%94.8'inde eczacıyla çalışan personel saptanmıştır (3). Yardımcı personel çalıştırma yüzdeleri arasındaki fark; 6. Bölgeki eczacıların maddi kazançlarını yeterli görme yüzdelerinin yüksek olması da göz önüne alındı̆̆ında o bölgedeki yoğun iş temposuna bağlanabilir. Eczacıların büyük bir kısmı 8 saatten fazla çalıştığı ve bu sürenin resmi kurumlarda çalışan meslektaşlarının çalıştığı süreden daha fazla olduğu belirlenmiştir.

Eczacıların mesleki memnuniyetleri incelendiğinde \% 14.8'inin memnun olmadıkları saptanmışken, Beken ve ark. araştırması'na göre o bölgedeki eczacıların \%25'inin mesleklerinden memnun olmadıkları belirlenmiştir (3). Şencan N.'nin uzmanlık tezine göre; eczane eczacılarının sadece beşte biri eczacı olarak çalışmaktan hoşnut olmadıklarını bildirmişlerdir (5). Son yapılan kanuni düzenlemelerin eczacıların mesleki memnuniyet durumlarına olumsuz bir etkide bulunmadığı düşünülebilir. Aylık ortalama kazançlarını yeterli bulma düzeyinin 6. Bölge eczacılarında daha yüksek olmasına karşın mesleki memnuniyet düzeyinin 9. Bölge eczacılarında daha yüksek olması, 9. Bölge eczacılarının mesleki memnuniyetleriyle aylık kazançları arasında direkt bir bağlantı olmadığı şeklinde değerlendirilebilir. Dokuzuncu Bölge eczacılarının mesleki memnuniyetlerine etki eden diğer faktörler arasında Keçiören bölgesinin Altındağ bölgesine kıyasla sosyokültürel ve ekonomik açıdan daha gelişmiş olması, daha planlı yerleşime sahip olması, vb olabilir. 
Eczacılara göre sağlık hizmetlerine yaptıkları katkıyı tamamen kavrayan gruplar arasında ilk sırayı yakın çevre (\%46.6), hiç kavramayan gruplar arasında yazılı ve görsel basın (\%32.9) almıştır. Eczacıların \% 13.6'sı hekimlerin, eczacıların sağlık hizmetlerine katkılarını hiç kavramadıklarını söylemiş̧ir. Beken S. ve arkadaşlarının yaptığı çalışmada eczacılara göre sağlık hizmetlerine yaptıkları katkıyı tamamen kavrayan gruplar arasında ilk sırayı yakın çevre (\%68.8), hiç kavramayan gruplar arasında yazılı ve görsel basın (\%67.5) almıştır. Eczacıların \%35.1'i hekimlerin sağlık hizmetlerine katkılarını hiç kavramadıklarını söylemişlerdir (3). Hekimlerin eczacıların sağlık hizmetine yaptıkları katkıyı kavramama görüşü, 6. bölge eczacıları arasında daha yaygındır. Bu, 9. Bölgede eczacı-hekim ilişkisinin 6. bölgeye göre daha iyi olmasına bağlanabilir. Sonuçta, her iki bölgede de eczacı-hekim ilişkisinde yetersizlik olduğu açıktır ve eczacı-hekim iletişimi yetkili kurumlarca (TEB ve Türk Tabipler Birliği-TTB) artırılarak bu sorunun üstesinden gelinebilir.

Eczacıların \%50.0'ı meslek hayatları sırasında, fakültelerinden aldıkları eğitimi uygulama imkanını yetersiz bulduklarını belirtmişlerdir. Beken ve ark. yaptı̆̆ çalışmada sonucunda ise bu değer \%64.9 olarak bulunmuştur. Eczacıların büyük bir kısmı üniversitede aldıkları eğitim ile serbest eczacılık işletmesinde karşılaştıkları problemlerin örtüşmediğini ifade etmişlerdir. Dolayısıyla eczacılık eğitimi yapan kurumların konuları belirlerken aşırı detaydan ziyade pratiğe yönelik konulara yer vermeleri uygun olacaktır.

Eczacılara göre eczacılık mesleğinin en önemli sorunu, sorunlu geri ödemeler (\%40.7), ikinci önemli sorunu da bürokrasidir (\%15.5). Beken ve ark. yaptığı çalışmada ise en önemli sorun ilaç katılım payı alınamaması (\% 18.1), ikinci önemli sorun ise kamu kurumlarının geri ödemelerindeki aksaklıktır (\% 15.4) (3). TEB çalışmasına göre eczacıların en önemli mesleki sorunu ilaç katılım paylarının alınamaması (\%20), ikinci önemli sorunu da kamu kurumlarının ödemelerindeki aksaklıklardır (\%15.1) (4). Tüm bu bulgulara göre eczacıların en önemli problemlerinin maddi konular ile ilgili olduğu görülmektedir. Önceki çalışmaların sonucunda sağlık sigorta sisteminin vatandaşın katkı payı ödemesi gerektirmeyecek yapıda olması ve güçlendirilmesinin bu sorunları çözebileceği belirtilmiştir (3). Önceki çalışmalarda en önemli sorun olarak çıkan ilaç katılım payının alınamaması sorunu, Ocak 2003'ten itibaren ilaç katılım payının kaynağından kesilmesini öngören yönetmeliğin uygulamaya girmesiyle Ankara 9. Bölgede yapılan çalışmada sorun olarak belirtilmemiştir. Bu sorunun ortadan kalkmasıyla beraber önceki çalışmalarda ikinci önemli sorun olarak bulunan kamu kurumlarının geri ödemelerindeki aksaklık son çalışmada ilk sırada bulunmuştur.

Eczacılara göre çalıştıkları bölgenin en önemli sağlı sorunları arasında ilk sırayı hastalıklar (\%47.2) almıştır. Beken ve ark. araştırması sonucunda ise ilk sırayı düşük sosyoekonomik düzey (\%25.0) almıştır. Ankara 9. Bölgedeki eczacıların bölgelerindeki sağlık sorunlarına sosyal açıdan ziyade tıbbi bir bakış açısıyla yaklaştıkları anlaşılmıştır.

Eczacıların büyük bir kısmı (\%44.3) kendilerinin sağlık hizmetlerine olan katkılarını "fena değil" olarak nitelendirmiştir. Eczacıların \%38.6'sı kendilerini yeterli olarak değerlendirmiştir. Beken ve ark. araştırmasında ise eczacıların \%45.4'ü "fena değil" ve 
\%32.5'i"yeterli" cevabını vermişlerdir. Buna göre eczacıların sağlık hizmetlerine olan katkılarını genel anlamda olumlu olarak değerlendirdikleri görülmektedir.

Eczacıların \% 19.1'inin MİEP düzenleyen kurumlar hakkında bilgilerinin olmadı̆̆ 1 görülmüştür. Bilgisi olanların büyük bir kısmı (\%86.1) AEO'nı, MİEP düzenleyen kuruluşlar arasında ilk sırada göstermişlerdir. Beken ve ark.'nın çalışması sonucunda MİEP hakkında hiçbir bilgisi olmayan eczacıların yüzdesi \%26.0 olarak bulunmuş ve bilgisi olanların (\%74.0) büyük bir kısmı yine AEO'nı MİEP düzenleyen kuruluşlar arasında ilk sırada göstermiştir. TEB'nin çalışmasına göre ise eczacıların \%63.3'ü AEO'nm MİEP düzenlediğini bilmektedir. Eczacıların yarısından fazla bir kısmı (\%61.0) MİEP'e ihtiyaç duymadıklarını belirtmiştir. MİEP'e ihtiyaç duyan kısım tarafından belirtilen konuların başında eczacılık uygulamalarıyla ilgili eğitim programları (\%54.4) ve hastalıklarla ilgili eğitim programlan (\%21.7) gelmektedir. TEB'nin çalışmasına göre eczacıların \%18.4'ü eczane işletmeciliği ve \%8.0'ı AP yöntemleri hakkında MİEP düzenlenmesini istemektedir (4). Bu sonuçlar da birbirlerini destekler nitelikte çıkmıştır. Eczacılık fakültesi müfredatında eczane işletmeciliği dersi bulunmaktadır. Bu ders kapsam olarak eczacılık tüzügünü içermektedir. Eczacılık fakültesinden mezun olanların çoğunun ileride serbest eczacılık yapacağı düşünülürse fakültede pratiğe dair bir eğitim verilmediği sonucuna varılabilir. Ayrıca, AP içeren bir ders verilmemektedir. Halk sağlığı dersi kapsamında bu konuya değinilmesi faydalı olabilir. MİEP düzenleme yetkisi olan kurum ve kuruluşların, eczacıların yetersiz olduklarını düşündükleri bu konulara önem vermelerinin gerekliliği aşikardır.

Eczacıların reçetelerde gözlediği yazım kurallarıyla ilgili eksikliklerin dağılımı incelendiğinde ilk sırayı reçetelerin okunaksız olması (\%53.9), ikinci sırayı doz yanlışlığı (\%51.7) almıştır. Beken ve ark. araştırması sonucunda da ilk sırayı \%42.9'la reçetelerin okunaksız yazılmasının, ikinci sırayı \%35.1'le dozların hatalı yazılmasının aldığı görülmektedir. Her iki bölgede yapılan çalışmada da benzer sorunlara dikkat çekilmiştir. Bu bilgiler doğrultusunda reçetelerin bazı hekimler tarafından özensiz ve hatalı yazıldığı anlaşılmıştır. Reçete yazma teknikleri konusunda hekimlerin ve hekim adaylarının belli bir eğitime tabi tutulmaları gerektiği kanaatine varılmıştır. Fakat, bu konunun sadece reçete yazma kuralları ile ilgili olmadığı, aynı zamanda hekimlerin ilaçlar konusundaki bilgi eksikliğine bağlı olabileceği de unutulmamalıdır. Ayrıca, hasta yükünün fazla olması ve zaman darlığı da reçete yazımındaki eksikliklere yol açmış olabilir.

Eczanelerden en sık talep edilen ilaç grubunun analjezikler olduğu saptanmıştır. Beken ve ark. araştırması sonucunda en sık temin edilen ilaç grubunun da analjezikler olduğu görülmüştür. Her iki çalışmada da reçetesiz verilen ilaçlar incelendiğinde, kırmızı ve yeşil reçeteye tabi ilaçlar dışındaki hemen hemen her grup ilacın verilebildiği görülmektedir. Reçetesiz alınan ilaç yelpazesinin bu denli geniş olması, ilaç tüketimi konusunda Türk toplumunun ne kadar bilinçsiz olduğunun bir göstergesidir. Ayrıca, birinci basamakta verilen sağlık hizmetlerine ulaşılmasının kolay olmasına rağmen doktora başvurmadan doğrudan eczacıya başvurulması, birinci basamakta verilen hizmetlerin öneminin yeterince anlaşılmadığının göstergesi olabilir. İlaç almak için doktora gitmeden doğrudan eczaneye gidenlerin (\%97.8) sayısının ne kadar fazla olduğu (Beken ve ark. çalışması sonucunda \%96.1) 
durumun ciddiyetini göstermektedir. Bu konuda halkın olduğu kadar eczacıların da bilinçlendirilmesi ve eğitilmesi gerekmektedir. Bu sayede akılcı ilaç kullanımı sağlanabilir. Ek olarak, bu konuda gerekli yasal düzenlemeler yapılabilir.

Eczacıların, eczanelerinde yaptıkları bazı tıbbi girişimler incelendiğinde enjeksiyon yapan 6 eczacı (Beken ve ark. araştırmasında 4 eczacı) saptanmıştır. Mevzuata göre eczacıların enjeksiyon yapma yetkisi bulunmamaktadır. Mevzuata göre eczacıların acil durumlarda ilaç verme yetkisi bulunmaktadır. Ancak, yapılan araştırmada eczacıların sadece \%6.7'sinin acil bir durum olan yüksek tansiyon düşürmek için ilaç verdiği görülmüştür (Beken ve ark. araştırması sonucunda \%11.7).

Günümüzde hipertansiyon önemli bir halk sağlık sorunudur. Çoğu yerde insanlar eczanelerde kan basınçlarını ölçtürmektedirler. Beken S. ve arkadaşlarının yaptığı çalışmada eczacıların \%46.8'i kan basıncı ölçtüklerini belirtmişken, 9. Bölgede yapılan çalışmada eczacıların \%82'si kan basıncı ölçtüklerini ifade etmişlerdir. Bu durum, eczacıların hastayı uygun sağlık kuruluşuna yönlendirmesi, takibi ve dolayısıyla halk sağlığı hizmeti sunması açısından iyi bir firsattır. Eczacılar mezuniyet öncesi dönemde bu konuda eğitilmelidirler.

Eczacıların \%29.2'si ilkyardım yapma konusunda kendilerini yetersiz bulduklarını ifade etmişlerdir. Beken ve ark. araştırması sonucunda ise eczacıların \%32.5'inin kendilerini yetersiz buldukları bulunmuştur. Bu durum, eczacıların mezuniyet öncesi ve sonrasında ilkyardım eğitimi almalarının önemini daha çok gözler önüne sermektedir. Bu eğitim uygulamalı ve beceride ustalaşmaya dayalı olmalıdır.

Eczacıların \%45.5'inin yetki ve sorumluluklarını düzenleyen yasal çerçeveyi yetersiz buldukları saptanmıştır. Beken ve ark. araştırması sonucunda ise eczacıların \%64.9'u yetersiz cevabı vermiştir. Yapılan üçüncü bir araştırmaya göre ise eczacıların yetki ve sorumluluklarını düzenleyen yasal çerçeve büyük bir yüzdeyle yetersiz bulunmaktadır (4). Bunun sebeplerinden biri eczacıların mevzuatı iyi bilmemeleri olabilir ya da mevzuatın güncelleştirilmemesi de buna yol açan bir faktör olabilir. Eczacıların yetki ve sorumluluklarını daha iyi öğrenmelerine yönelik bilgilendirici programlar düzenlenmesi faydalı olabilir.

Son üç ayda eczanelerden ilaç alımında azalma olduğunu belirten 61 eczacı (\%68.5) saptanmıştır. Eczacıların \%25.8'i ilaç alımındaki azalmaya sebep olarak ekonomik krizi belirtmişlerdir. Türkiye'nin içinde bulunduğu ekonomik koşullar gözönüne alınırsa bu durum şaşırtıcı değildir.

Eczacıların son çıkan, Emekli Sandığı'nın eş değer ilaç uygulaması ile ilaç katılım paylarının kaynağından kesilmesi konusundaki görüşleri incelendiğinde; eczacıların \%92.2'sinin Emekli Sandığı'nın eş değer ilaç uygulamasından memnun olmadığı, ancak \%92.1'inin ilaç katılım payının kaynağından kesilmesinden memnun olduğu belirlenmiştir. Emekli Sandığı'nın eş değer ilaç uygulamasından memnun olmayan eczacıların \%59.0'ı gerekçe olarak hastalarla yaşanan sorunları göstermişlerdir. İlaç katılım payının kaynağından kesilmesinden memnun olan eczacılar ise hastalarla yaşanan para sorununun çözülmesini (\%54.2) gerekçe olarak göstermişlerdir. İlaç katılım payının kaynağından kesilmesinin gereksiz ilaç alımını azalttığı ve bu genelgeyle devletin hedeflediği ekonomik kazancın büyük oranda 
gerçekleşebileceği anlaşılmaktadır. Ancak, eşdeğer ilaç uygulaması konusunda yeterli alt yapı çalışmaları yapılmadan, başlanmış olduğu düşünülmüsstür. Eczacılar özellikle eş değer ilaç uygulamasına hazırlıksız yakalanmış ve pahalı ilaçların ellerinde kalmasından dolayı büyük ölçüde maddi zarara uğramışlardır. Bu eczacıların çoğu genelgenin aceleye getirildiğini ifade etmişlerdir. Genelge halka yeterince izah edilmediği için eczacı ve hasta karşı karşıya kalmakta ve hasta, problemlerinin çözümünü eczacıdan beklemektedir. Kitle iletişim araçlarından faydalanarak eşdeğer ilaç kavramı konusunda halkın bilgilendirilmesi, eczacıların ve halkın bu sıkıntılarını gidermekte faydalı olacaktır.

\section{SONUÇ}

Ankara 9. bölgede çalışan eczacıların \% 14.8'i eczacı olmaktan memnun değildir. Yüzde 17.1 'i sağlık hizmetlerine olan katkılarını yetersiz bulmaktadır. Onlara göre eczacılık mesleğinin en önemli sorunu; "sorunlu geri ödemeler (\%40.8)" dir. Eczacıların \%68.5'i son üç aydır ilaç alımının azaldığını ifade etmiştir. Böyle söyleyenlerin \%25.8'i ekonomik krizi, bu azalmanın gerekçesi olarak belirtmiştir. Eczacıların \%92.1'inin Emekli Sandığı'nın eşdeğer ilaç uygulamasından memnun olmadıkları, \%92.1'inin ilaç katılım paylarının kaynağından kesilmesi uygulamasından memnun oldukları anlaşılmışır.

\section{KAYNAKLAR}

1. Eczacılık Tarihi; http ://www .geocities .com/kirmizitas/tarihce .html, (27.03.2003).

2. İyi Eczacılık Uygulamaları Kılavuzu, Sağlık Bakanlığı İlaç Ve Eczacılık Genel Müdürlüğü'nün 26.05.2003 Tarih, $23775 \quad$ Sayılı Tebliği, http://www.geocities.com/kirmizitas/gmp.html, (09.10.2003).

3. Altıntaş, H., Coşkun A., Beken S., Bozkuş Y., Bulut S., Büyükkmacı M., Çalıdă̆ E., Ankara 6. Bölge Eczanelerinde Çalışan Eczacıların Bazı Mesleki Uygulamalarını ve Sorunlarını Saptama Araştırması Tebliği, HÜTF Halk Sağlığı AD, 8. Halk Sağlığı Günleri, Sivas, 23-25 Haziran 2003.

4. Türk Eczacıları Birliği Araştırma Dizisi, Eczacı Profili Araştırması, Ankara, (1999).

5. Sencan N., Ankara İlindeki Hastane ve Eczane Eczacılarının İş Doyumuna Yönelik Uzmanlık Tezi, Ankara, (1994) 